\title{
A conserved biosynthetic gene cluster is regulated by quorum sensing in a shipworm symbiont
}

\#Present address:

\author{
Jose Miguel D. Robes ${ }^{1,2,3}$, Marvin A. Altamia ${ }^{3 \#}$, Ethan G. Murdock ${ }^{1,2}$, Gisela P. Concepcion ${ }^{3}$, \\ Margo G. Haygood ${ }^{4}$, and Aaron W. Puri ${ }^{1,2 *}$ \\ ${ }^{1}$ Department of Chemistry, University of Utah, Salt Lake City, Utah, USA \\ ${ }^{2}$ Henry Eyring Center for Cell and Genome Science, University of Utah, Salt Lake City, Utah, USA \\ ${ }^{3}$ The Marine Science Institute, University of the Philippines Diliman, Quezon City, Philippines \\ ${ }^{4}$ Department of Medicinal Chemistry, University of Utah, Salt Lake City, Utah, USA
}

14 Marvin A. Altamia, Ocean Genome Legacy Center, Department of Marine and Environmental Science, 15 Northeastern University, Nahant, Massachusetts, USA

17 *Corresponding author:

18 Aaron W. Puri

19315 S 1400 E Rm 2020

20 Salt Lake City, UT 84112

21 USA

22 (801) 213-1408

23 a.puri@utah.edu 


\section{ABSTRACT}

Bacterial symbionts often provide critical functions for their hosts. For example, wood-boring bivalves called shipworms rely on cellulolytic endosymbionts for wood digestion. However, how the relationship between shipworms and their bacterial symbionts is formed and maintained remains unknown. Quorum sensing (QS) often plays an important role in regulating symbiotic relationships. We identified and characterized a QS system found in Teredinibacter sp. strain 2052S, a gill isolate of the wood-boring shipworm Bactronophorus cf. thoracites. We determined that $2052 \mathrm{~S}$ produces the signal $N$-decanoyl- $L$ homoserine lactone $\left(\mathrm{C}_{10}\right.$-HSL), and that this signal controls activation of a biosynthetic gene cluster colocated in the symbiont genome that is conserved among all symbiotic Teredinibacter isolates. We subsequently identified extracellular metabolites associated with the QS regulon, including ones linked to the conserved biosynthetic gene cluster, using mass spectrometry-based molecular networking. Our results demonstrate that QS plays an important role in regulating secondary metabolism in this shipworm symbiont. This information provides a step towards deciphering the molecular details of the relationship between these symbionts and their hosts. Furthermore, because shipworm symbionts harbor vast yet underexplored biosynthetic potential, understanding how their secondary metabolism is regulated may aid future drug discovery efforts using these organisms.

\section{IMPORTANCE}

Bacteria play important roles as symbionts in animals ranging from invertebrates to humans. Despite this recognized importance, much is still unknown about the molecular details of how these relationships are formed and maintained. One of the proposed roles of shipworm symbionts is the production of bioactive secondary metabolites due to the immense biosynthetic potential found in shipworm symbiont genomes. Here, we report that a shipworm symbiont uses quorum sensing to coordinate activation of its extracellular secondary metabolism, including the transcriptional activation of a biosynthetic gene cluster that is conserved among many shipworm symbionts. This work is a first step towards linking quorum sensing, secondary metabolism, and symbiosis in wood-boring shipworms. 
Wood-boring shipworms are bivalves that harbor intracellular gammaproteobacteria in their gills that express cellulases for wood digestion $(1,2)$. However, many details of the molecular mechanisms that govern the selection and maintenance of symbiotic bacteria by shipworms remain unknown. Analysis of published endosymbiont genomes and shipworm-associated metagenomes has indicated that these gill endosymbionts are also capable of producing a plethora of secondary metabolites comparable to wellknown producers such as Streptomyces spp. (3). Several predicted biosynthetic gene clusters (BGCs) are conserved among shipworm symbionts (3), which could indicate that the products of these clusters play a role in the symbiotic relationship. For example, the boronated antibiotic tartrolon, isolated from the shipworm symbiont Teredinibacter turnerae T7901, is hypothesized to participate in the inhibition of competing parasites in the shipworm gills and/or cecum (4).

Bacterial symbionts often use quorum sensing (QS) to coordinate group behavior, which is thought to help differentiate between a low-density, free-living state, and high-density, host-associated state (5). In many proteobacteria, QS is mediated by acyl-homoserine lactone (acyl-HSL) signals produced by LuxIfamily synthases (6). In this type of QS system, genes are regulated by members of the LuxR-family of transcription factors which bind and respond to acyl-HSLs (6). The first QS system was characterized in the invertebrate symbiont Aliivibrio fischeri, which uses 3-oxo-hexanoyl-L-homoserine lactone (3-oxo- $\mathrm{C}_{6-}$ HSL) to regulate bioluminescence in the light organ of its host squid, Euprymna scolopes (7, 8). Characterization of QS systems in shipworm symbionts therefore has the potential to provide insight into the details of their relationship with their host.

QS often regulates the production of extracellular factors, including secondary metabolites and enzymes such as proteases $(6,9-11)$. A common example is the plant-associated pathogen, Erwinia carotovorum, which is known to produce the antibiotic carbapenem in response to QS (9). In many cases QS systems regulate adjacent genes in bacterial genomes, and a recent genome mining effort discovered that BGCs neighboring $l u x R$ homologs are widespread in proteobacteria (12). Interestingly, only a small percentage of QS-linked BGCs identified in this study were found in free-living and invertebrate-associated bacteria, while plant- and human-associated bacteria made up the majority (12).

One BGC of interest that is found in all cellulolytic shipworm symbionts isolated to date is a predicted hybrid trans-AT PKS-NRPS (trans-acyltransferase polyketide synthase-nonribosomal peptide synthetase) gene cluster termed GCF_3 (3). The product of GCF_3 has not been isolated or characterized. Teredinibacter sp. strain PMS-2052S.S. Stab0a.01 (referred to here as 2052S) is a cellulolytic bacterial strain isolated from the gills of a specimen of the shipworm Bactronophorus cf. thoracites collected in Butuan, Agusan del Norte, Philippines. In the genome of 2052S, the GCF_3 BGC is adjacent to a predicted QS system. Determining how this $\mathrm{BGC}$ is regulated in a symbiont may enable the identification and characterization of its product.

In this work, we characterized the QS system used by the shipworm endosymbiont 2052S. We identified the acyl-HSL signal and linked it with its cognate synthase and receptor. We then determined that this QS system regulates the neighboring GCF_3 BGC, and used untargeted metabolomics and molecular networking to identify metabolites associated with the QS regulon including potential products of the GCF_3 BGC. To our knowledge, this is the first characterization of a shipworm endosymbiont QS system, which extends our understanding of the molecular details of this symbiosis. 


\section{A conserved biosynthetic gene cluster in cellulolytic shipworm symbionts is adjacent to quorum} sensing genes in strain $2052 \mathrm{~S}$

The cellulolytic strain $2052 \mathrm{~S}$ was isolated from the gills of a specimen of the wood-boring shipworm Bactronophorus cf. thoracites (see Table S1 for strain isolation information) (3). It is likely an intracellular symbiont like other Teridinibacter species (1), however more studies will be needed to determine this definitively. In the genome of 2052S, the conserved BGC GCF_3 is adjacent to a luxRfamily transcription factor gene (K256DRAFT_2894, tbaR) and an acyl-HSL synthase gene (K256DRAFT_2894, tbaI) (Figure 1A). We therefore hypothesized that GCF_3 may be regulated by QS in this strain, as is true with other QS-linked BGCs in proteobacteria $(10,11)$. In other shipworm symbionts, GCF 3 is not adjacent to QS genes (Figure S1), indicating that QS may have been lost in those isolates or gained in 2052S.

We also found QS genes adjacent to BGCs in the genomes of other shipworm symbionts (Figure S2). However, these BGCs had low similarity to GCF_3, suggesting that QS may regulate the production of other secondary metabolites in these strains. Notably, Teredinibacter turnerae, the most wellcharacterized shipworm symbiont, does not harbor a luxI-family synthase gene or complete luxR-family transcription factor gene. We have thus far only identified predicted QS systems in isolates from woodboring shipworms that are not dominated by T. turnerae (3).

A

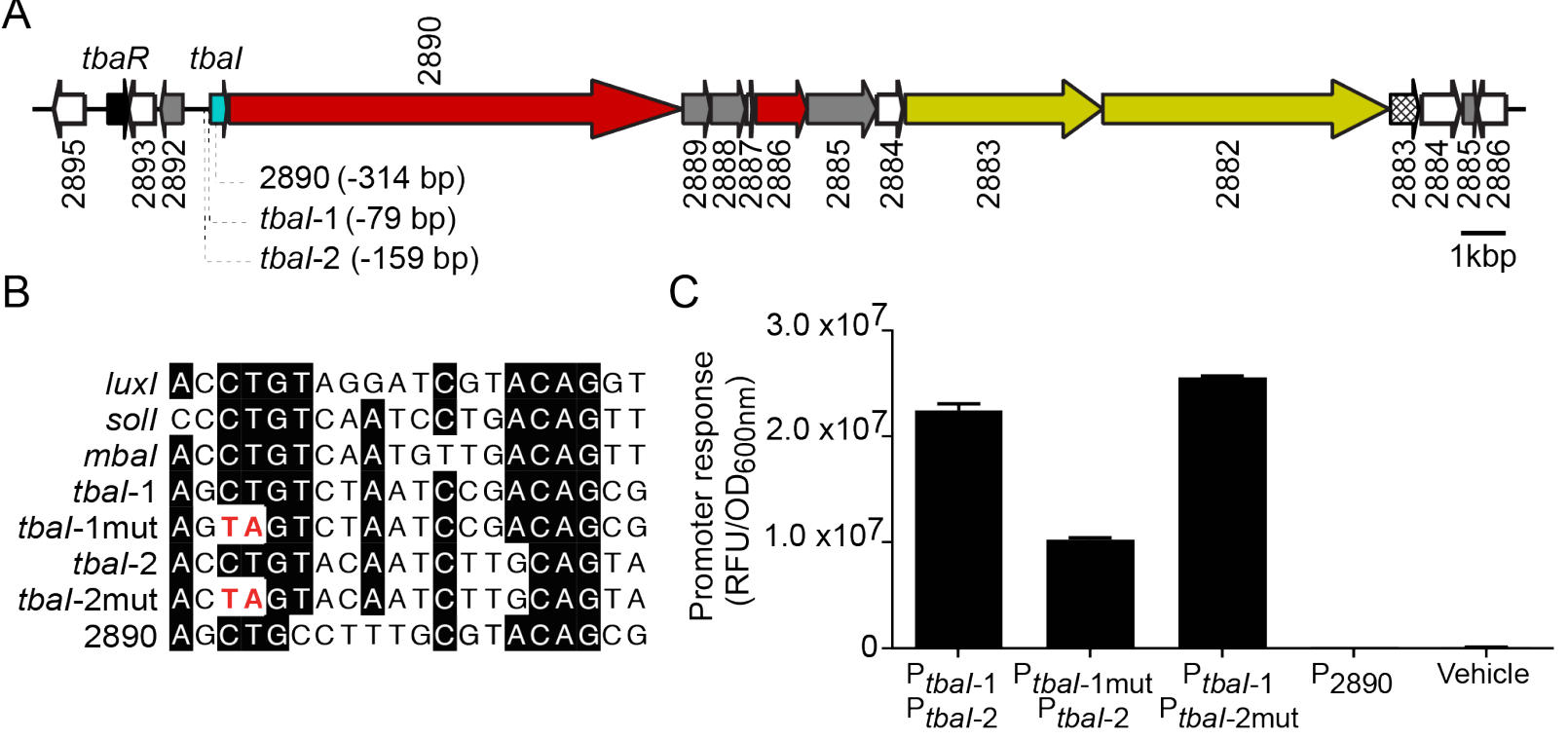

Figure 1. A quorum sensing system in the Teredinibacter sp. strain $2052 \mathrm{~S}$ genome is adjacent to a conserved biosynthetic gene cluster. (A) Quorum sensing genes ( $t b a I$ and $t b a R$ ) neighbor a predicted hybrid trans-AT-PKSNRPS biosynthetic gene cluster (3). Identified putative TbaR-binding sites are represented by dotted lines from their position in the cluster, and list the number of base pairs they are located upstream of the start codon of the indicated gene. Numbers correspond to locus tags (K256DRAFT_XXXX) in the Joint Genome Institute Integrated Microbial Genomes (IMG) system (14). Genes are colored as follows according to predicted function in antiSMASH 6.0 (15): luxI-family acyl-HSL synthase gene $t b a I$, cyan; luxR-family transcription factor gene $t b a R$, black; polyketide synthase genes, red; nonribosomal peptide synthetase genes, yellow; other biosynthetic gene, gray; efflux pump gene, cross-hatched; other genes, white. (B) Comparison of putative TbaR-binding sites upstream of the acyl-HSL synthase gene tbaI and PKS gene 2890 with known LuxR-type binding sites in the promoter sequences of Aliivibrio fischeri luxI, Ralstonia solanacearum solI, and Methylobacter tundripaludum mbaI. (C) Response of E. coli reporter strains containing $g f p$ fused to different promoter regions with putative TbaR-binding sites shown in $1 \mathrm{~B}$ to $100 \mathrm{nM}$ $\mathrm{C}_{10}$-HSL or ethyl acetate (vehicle). Data are the mean \pm standard deviation of three technical replicates and are representative of two independent experiments. 
We characterized the 2052S QS system by first determining if this strain can produce and respond to a QS signal under laboratory conditions. We identified two potential LuxR-family binding sites upstream of the tbaI acyl-HSL synthase gene (Figures 1A, 1B), which is often positively autoregulated by its cognate LuxR-family transcription factor upon signal binding (6). We then constructed a two-plasmid reporter system $\left(\mathrm{P}_{t b a l}-g f p\right)$ in Escherichia coli in which one plasmid expresses tbaR under its native promoter and the other plasmid contains the $t b a I$ promoter, which includes the putative LuxR-family binding sites, fused to $g f p$. Adding organic extract of supernatant from a wild-type (WT) 2052S culture to the $\mathrm{P}_{t b a l}-g f p$ reporter strain resulted in a significant increase in GFP fluorescence compared to a solvent control (Figure S3). This confirms that $2052 \mathrm{~S}$ produces a QS signal and that the LuxR-family homolog, TbaR, binds this signal and activates $t b a I$ expression in a positive feedback loop. We then determined which of the two putative binding sites is primarily used by TbaR by
constructing two separate reporter strains containing a CT to TA mutation in the conserved region of each site (Figure 1B). We found that GFP fluorescence was unaffected when the mutation was introduced in $\mathrm{P}_{t b a I-2}$, suggesting that $\mathrm{P}_{t b a I-1}$ is the primary TbaR binding site (Figure 1C). However, mutating $\mathrm{P}_{t b a I-l}$ did not completely abolish $g f p$ activation, suggesting that TbaR can also bind $\mathrm{P}_{t b a I-2}$ in the absence of $\mathrm{P}_{t b a I-1}$.

In order to isolate and characterize the acyl-HSL signal produced by $2052 \mathrm{~S}$, we separated organic supernatant extract by HPLC and tested each fraction using the $\mathrm{P}_{t b a l}-g f p$ reporter strain. This resulted in one peak of GFP fluorescence in two adjacent fractions, which was not present in supernatant from an unmarked, in-frame $\Delta t b a I$ mutant we constructed using sucrose counterselection (Figure 2A). We detected a feature with an $\mathrm{m} / \mathrm{z}$ of 256 in the pooled active fractions using LC-MS, which is consistent with the protonated mass of $N$-decanoyl- $L$-homoserine lactone $\left(\mathrm{C}_{10}-\mathrm{HSL}\right)$.
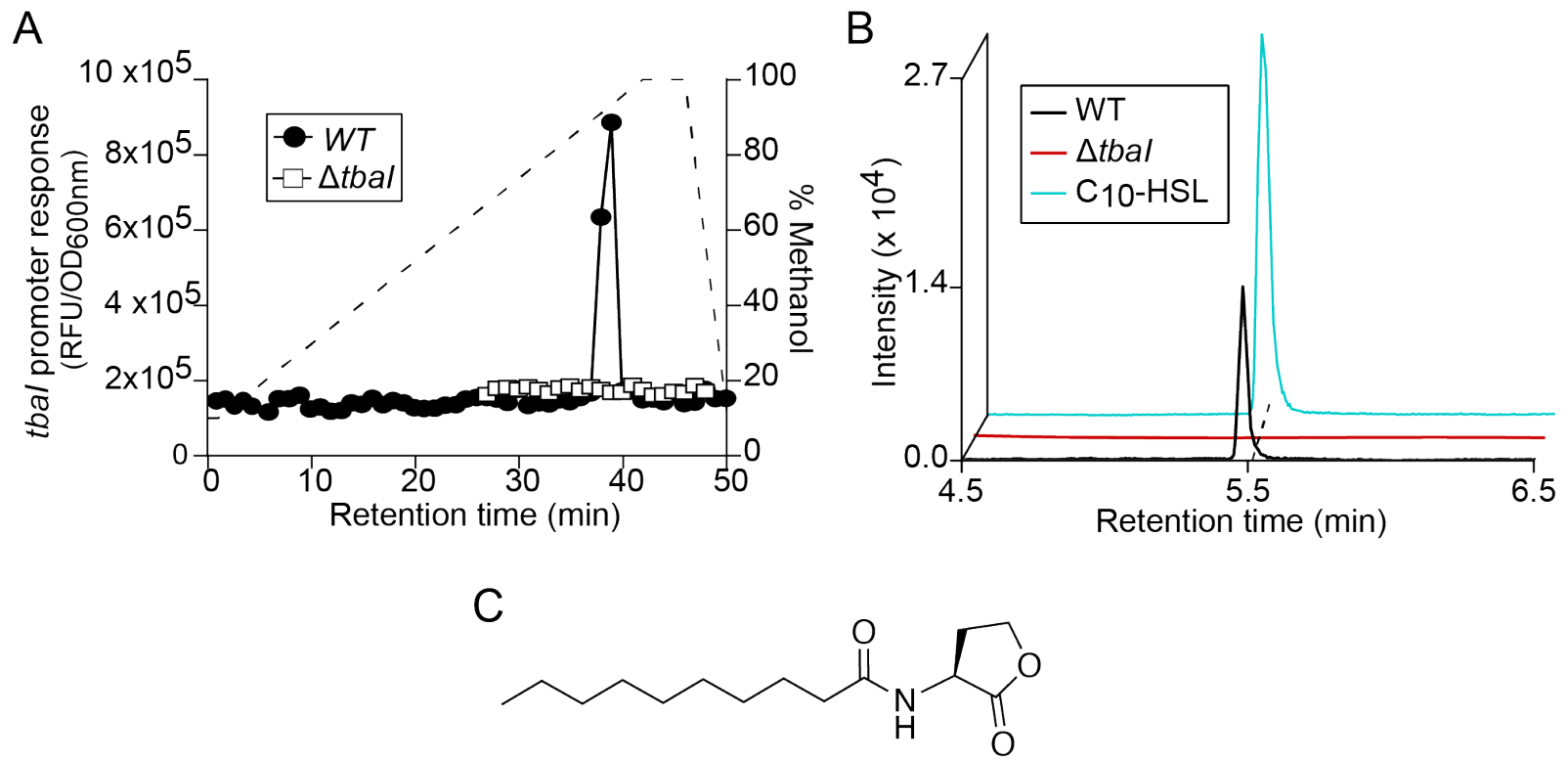

Figure 2. Teredinibacter $\mathrm{sp}$. strain $2052 \mathrm{~S}$ produces the quorum sensing signal $\mathrm{C}_{10}$-HSL. (A) $\mathrm{P}_{t b a l}-g f p$ activity of HPLC-fractionated culture supernatant extracts from wild-type and $\Delta$ tbaI strains of 2052S. The dashed line shows the methanol gradient. (B) Extracted ion chromatogram of supernatant extracts of wild-type and $\Delta t b a I$ strains of 2052S compared to commercial $\mathrm{C}_{10}$-HSL signal for $\mathrm{m} / \mathrm{z} 279.1812$, corresponding to the sodium adduct of $\mathrm{C}_{10}$ HSL. Mass tolerance $<5 \mathrm{ppm}$. (C) Structure of $\mathrm{C}_{10}-\mathrm{HSL}$. 
indistinguishable from the commercial standard (Figure 2B, Table S2). Furthermore, the $\mathrm{P}_{t b a l}-g f p$ reporter strain was found to be responsive to the commercial standard (Figure S4), and we used the $\mathrm{P}_{t b a r}-g f p$ reporter assay to determine that $2052 \mathrm{~S}$ produces approximately $250 \pm 22 \mathrm{nM}$ signal during early stationary phase $\left(\mathrm{OD}_{600 \mathrm{~nm}}=1.2,32\right.$ hours $)$. Together, these results demonstrate that the bacterial endosymbiont $2052 \mathrm{~S}$ produces and responds to the quorum sensing signal $\mathrm{C}_{10}-\mathrm{HSL}$.

\section{Transcription of the conserved biosynthetic gene cluster GCF_3 is regulated by quorum sensing in $2052 S$}

We next sought to determine what $2052 \mathrm{~S}$ regulates using QS. The $\Delta t b a I$ mutant is still capable of using cellulose as its primary carbon source, indicating that cellulase production is not regulated by QS in 2052S (all experiments used cellulose as the carbon source, see also Figure S5). We noticed a significant change in the pigmentation of the $\Delta t b a I$ culture, which we could partially complement by adding exogenous $\mathrm{C}_{10}$-HSL (Figure 3A). This suggests that QS may play a role in regulating secondary metabolite production in 2052S. We used RT-qPCR to determine if the conserved GCF_3 BGC adjacent to the QS genes in the 2052S genome is regulated by QS. We quantified the transcription of core genes in this cluster (K256DRAFT_2890, K256DRAFT_2886, and K256DRAFT_2881) in the WT, $\Delta t$ tbaI mutant, and $\Delta t b a I$ mutant chemically complemented with $\mathrm{C}_{10}-\mathrm{HSL}$. All three core biosynthetic genes were found to be expressed in a QS signal-dependent manner in a late log-phase culture $\left(\mathrm{OD}_{600 \mathrm{~nm}}=0.8,24\right.$ hours) (Figure 3B).

A
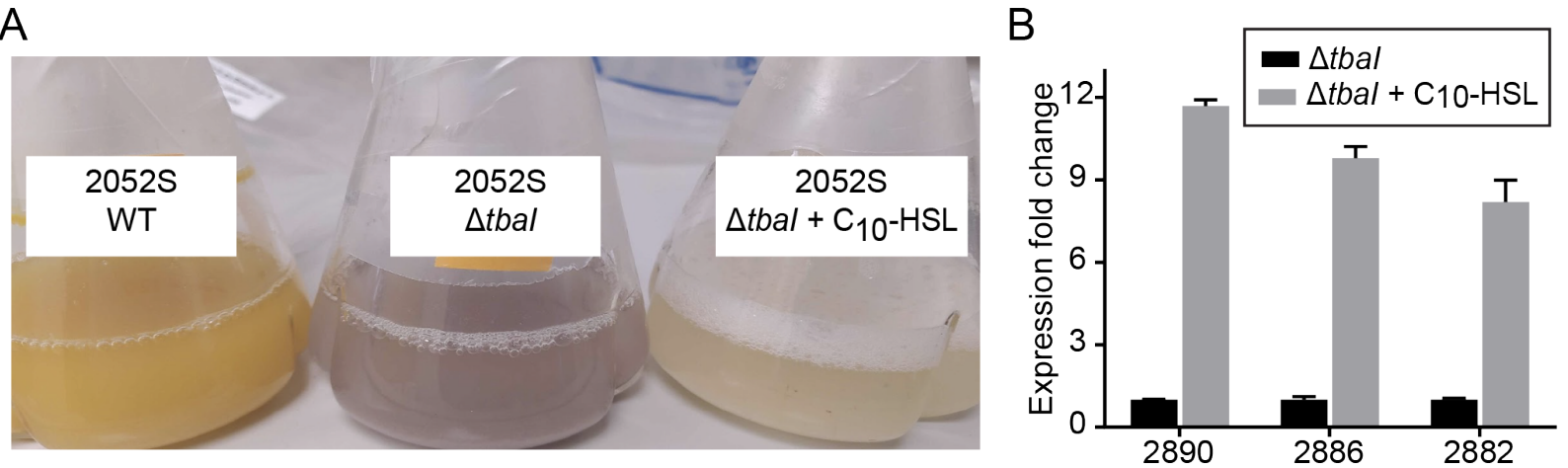

Figure 3. The conserved BGC is transcriptionally activated by the addition of $\mathrm{C}_{10}-\mathrm{HSL}$ in the $\Delta t b a I$ mutant. (A) Pigmentation phenotype of wild-type (left) and $\Delta t b a I$ (middle) cultures, and partial reversion to wild-type phenotype upon addition of QS signal to $\triangle t b a I$ culture (right). (B) RT-qPCR results showing relative expression of GCF_3 genes K256DRAFT_2890, 2886, and 2882 upon addition of C 10 -HSL to the $\Delta t b a I$ strain normalized to $\triangle t b a I$ expression in the absence of signal. Data are the mean \pm standard deviation of three technical replicates and are representative of two independent experiments.
The first gene in the GCF_3 cluster is K256DRAFT_2890, which encodes a predicted multidomain trans-AT-PKS. We identified a putative TbaR-binding site upstream of K256DRAFT_2890 within the tbaI gene (Figures 1A, 1B). However, when we created a reporter strain containing this upstream region, it did not drive $g f p$ expression in response to $\mathrm{C}_{10}$-HSL (Figure 1C). This suggests that both tbaI and K256DRAFT_2890 are transcribed together in the same operon, which we confirmed by RT-PCR (Figure S6). Together, these results demonstrate that $2052 \mathrm{~S}$ uses QS to coordinate the activation of the conserved GCF_3 BGC.

\section{QS regulates the majority of the extracellular metabolome of $2052 \mathrm{~S}$}

Because GCF_3 contains predicted efflux pumps (Figure 1A), we sought to identify changes in the extracellular metabolome of 2052S that are controlled by QS in order to determine which secondary metabolites are linked to this cluster. We first constructed an unmarked, in-frame deletion mutant of the $1.3 \mathrm{~kb}$ polyketide synthase gene K256DRAFT_2886 ( $\Delta 2886)$, and also complemented this mutant using a 
plasmid containing K256DRAFT_2886 driven by the 2052S rpoD promoter (pAWP275). We then used untargeted metabolomics to compare crude organic supernatant extracts from stationary phase cultures of WT $2052 \mathrm{~S}$, the $\Delta t b a I$ mutant, the $\Delta t b a I$ mutant supplemented with $\mathrm{C}_{10}-\mathrm{HSL}$, the $\Delta 2886$ mutant, and the $\Delta 2886$ mutant complemented with pAWP275. Products Social molecular networking (GNPS) platform, which clusters metabolites based on MS/MS fragmentation patterns (13). This analysis produced a primary dataset of 442 features from raw LC-MS/MS scans. We further refined this dataset by removing features found in the uninoculated growth medium as well as those not found in both independent replicates, resulting in a final dataset of 256 features (Figure 4A). The majority $(175 / 256,68 \%)$ of features were only detectable in the supernatant of QS-active strains (Figure 4B). This indicates that QS plays an important role in the regulation of secondary metabolism in this shipworm endosymbiont. Notably, none of the 2052S extracellular secondary metabolites had matches to compounds in the GNPS spectrum library. This highlights the potentially unique biosynthetic potential of shipworm endosymbionts.

To identify the putative product of the GCF_3 BGC in 2052S, we focused on extracellular 191 metabolites present in cultures of the WT, the $\Delta t b a I$ mutant supplemented with $\mathrm{C}_{10}-\mathrm{HSL}$, and the $\Delta 2886$ 192 mutant complemented with pAWP275, but absent in the $\Delta t b a I$ and $\Delta 2886$ mutants. We identified two 193 putative metabolites matching this pattern that may be products of this gene cluster (Figures 4C, 4D), 194 including a feature with a precursor ion mass of $394.2985 \mathrm{~m} / \mathrm{z}$ found in the largest cluster in the network 195 (Figure 4A). This cluster was found almost exclusively in QS-active samples. These metabolites will require further investigation to determine their structure and function.

We have identified and characterized a QS system in Teredinibacter sp. strain 2052S, a symbiont of the wood-boring shipworm $B$. cf. thoracites. We determined that $2052 \mathrm{~S}$ produces and responds to the signal $\mathrm{C}_{10}$-HSL, and that this signal regulates the activation of a $\mathrm{BGC}$ that is conserved among all woodboring shipworm symbiont isolates, termed GCF_3. It is possible that secondary metabolites produced by shipworm endosymbionts play a role in establishing and maintaining the relationship between these bacteria and their host. The discovery of a symbiont that regulates its extracellular secondary metabolism using QS is consistent with this hypothesis, as QS is often thought to enable bacterial symbionts to differentiate between planktonic and host-associated states. More studies will be needed to understand the role of these metabolites, as well as QS, in this symbiotic relationship. 
A
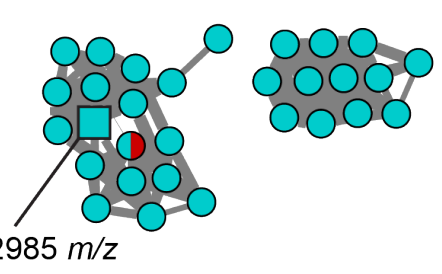
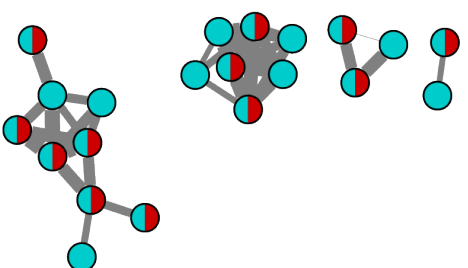

$464.2708 \mathrm{~m} / \mathrm{z}$
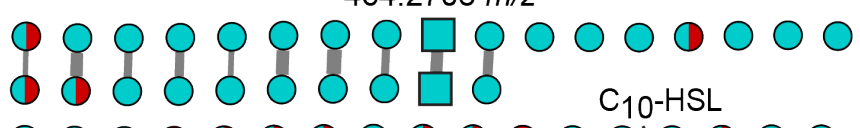

$0000000000000 j 00000$ 000000000000000000 000000000000000000 000000000000000000 000000000000000000 000000000000000000 000000000000000000 000000000000000000 000000000000000000 0000000000000000 OQS on OQS off Feature associated with GCF_3

C

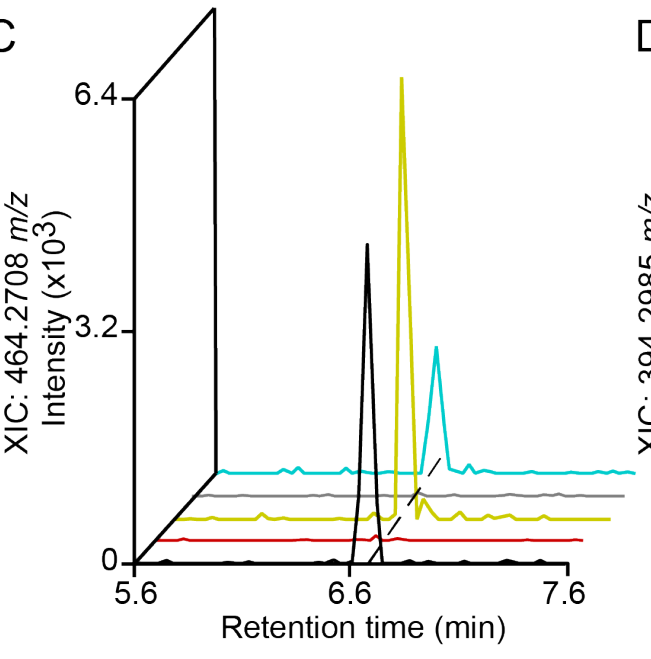

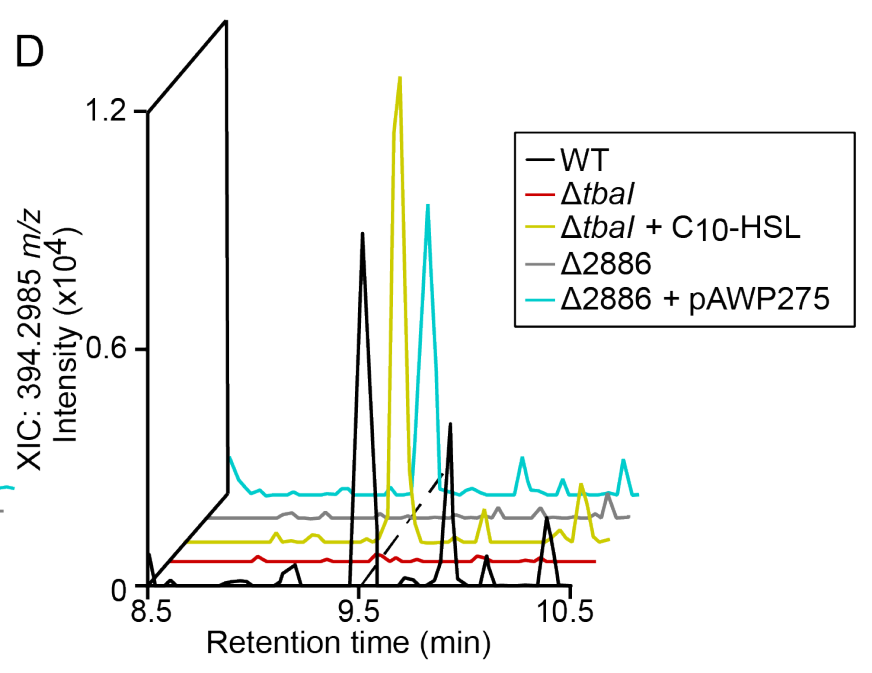

Figure 4. Quorum sensing regulates the majority of extracellular metabolites produced by 2052S. (A) Molecular network of untargeted metabolomics data of supernatant extracts from cultures of WT, $\Delta t b a I$, and $\Delta t b a I$ supplemented with $\mathrm{C}_{10}-\mathrm{HSL}$. Features found in samples where QS is on (WT, $\Delta t b a I+\mathrm{C}_{10}-\mathrm{HSL}$ ) are shown as cyan nodes, features found in the $\Delta t b a I$ culture, where QS is off, are shown as red nodes, and features found in both samples where QS is on and off are shown as split cyan and red nodes. Features identified as associated with GCF_3 (present in WT, $\Delta t b a I+\mathrm{C}_{10}-\mathrm{HSL}$, and $\Delta 2886+$ pAWP275, but absent in $\Delta t b a I$ and $\Delta 2886$ ) are shown as square nodes, and $\mathrm{C}_{10}-\mathrm{HSL}$ is shown as a hexagonal node. Edge width is scaled with cosine similarity score. (B) Venn diagram of features associated with the QS regulon. (C,) Extracted ion chromatogram of $\mathrm{m} / \mathrm{z} 464.2708$ in culture supernatant extracts. Mass tolerance $<5 \mathrm{ppm}$. (D) Extracted ion chromatogram of $\mathrm{m} / z 394.2985$ in culture supernatant extracts. Mass tolerance $<5 \mathrm{ppm}$. 


\section{MATERIALS AND METHODS}

\section{Plasmid Construction}

All plasmids were constructed using Gibson assembly (16), with the exception of the reporter plasmids pAWP239, pAWP381, pAWP479, and pAWP480, which were constructed by inserting upstream gene sequences into the promoter probe plasmid pPROBE-GFP[LVA] (17) at the EcoRI and SacI restriction sites. The upstream sequences in pAWP479 and pAWP480, which contain CT-to-TA mutations, were ordered as gBlocks from Integrated DNA Technologies. Plasmids and primers used in this study are listed in Table 1 and Table 2, respectively.

\section{Strain Growth}

Strains used in this study are listed in Table 1. E. coli strains were grown in lysogeny broth (LB) at $37^{\circ} \mathrm{C}$. Teredinibacter sp. strain PMS-2052S.S.stab0a.01 (2052S) was isolated from Bactronophorus cf. thoracites (PMS-1959H) collected from Butuan, Agusan del Norte, Philippines (Table S1) and was grown on shipworm basal media $\left(30^{\circ} \mathrm{C}, 200 \mathrm{rpm}\right)$ as previously described by Waterbury et al. (1983) (2). SBM contains $\mathrm{NaCl}(19.8 \mathrm{~g} / \mathrm{L}), \mathrm{NH}_{4} \mathrm{Cl}(267.5 \mathrm{mg} / \mathrm{L}), \mathrm{MgCl}_{2} \cdot 6 \mathrm{H}_{2} \mathrm{O}(8.95 \mathrm{~g} / \mathrm{L}), \mathrm{Na}_{2} \mathrm{SO}_{4}(3.31 \mathrm{~g} / \mathrm{L}), \mathrm{CaCl}_{2} \cdot 2 \mathrm{H}_{2} \mathrm{O}$ $(1.25 \mathrm{~g} / \mathrm{L}), \mathrm{NaHCO}_{3}(0.162 \mathrm{~g} / \mathrm{L}), \mathrm{Na}_{2} \mathrm{CO}_{3}(10 \mathrm{mg} / \mathrm{L}), \mathrm{KCl}(0.552 \mathrm{mg} / \mathrm{L}), \mathrm{KBr}(81 \mathrm{mg} / \mathrm{L}), \mathrm{H}_{3} \mathrm{BO}_{3}(21.5$ $\mathrm{mg} / \mathrm{L}), \mathrm{SrCl}_{2} \cdot 6 \mathrm{H}_{2} \mathrm{O}(19.8 \mathrm{mg} / \mathrm{L}), \mathrm{KH}_{2} \mathrm{PO}_{4}(3.82 \mathrm{mg} / \mathrm{L}), \mathrm{NaF}(2.48 \mathrm{mg} / \mathrm{L}), \mathrm{Na}_{2} \mathrm{MoO}_{4} \cdot 2 \mathrm{H}_{2} \mathrm{O}(2.5 \mathrm{mg} / \mathrm{L})$, $\mathrm{MnCl}_{2} \cdot 4 \mathrm{H}_{2} \mathrm{O}(1.8 \mathrm{mg} / \mathrm{L}), \mathrm{ZnSO}_{4} .7 \mathrm{H}_{2} \mathrm{O}(0.22 \mathrm{mg} / \mathrm{L}), \mathrm{CuSO}_{4} \cdot 5 \mathrm{H}_{2} \mathrm{O}(0.079 \mathrm{mg} / \mathrm{L}), \mathrm{Co}\left(\mathrm{NO}_{3}\right)_{2} \cdot 6 \mathrm{H}_{2} \mathrm{O}(0.049$ $\mathrm{mg} / \mathrm{L})$, Fe-EDTA complex $(4.15 \mathrm{mg} / \mathrm{L})$, and HEPES $(4.76 \mathrm{~g} / \mathrm{L})$ adjusted to $\mathrm{pH}=8.0$. The carbon source used was Sigmacell cellulose type $101(0.2 \mathrm{~g} / \mathrm{L})$.

\section{Genetic Manipulation}

Genetic manipulation of all strains derived from wild-type $2052 \mathrm{~S}$ were performed at $30^{\circ} \mathrm{C}$. Verified plasmids were conjugated into 2052S using the E. coli donor strain S17-1 (18) using the following method. $500 \mu \mathrm{L}$ of exponentially growing cultures of donor and recipient strains were pelleted and washed with sterile ultrapure water. The two pellets were then combined in a total volume of $50 \mu \mathrm{L}$ and spotted onto an SBM plate containing $10 \%(\mathrm{v} / \mathrm{v})$ nutrient broth, and subsequently incubated for two days. Successful conjugants were selected on SBM plates containing kanamycin $\left(50 \mu \mathrm{g} \mathrm{m}^{-1}\right)$. To construct the unmarked deletion mutants $\Delta t b a I$ and $\Delta 2886$, kanamycin-resistant integrants (single crossovers) were restreaked and grown in SBM broth with no kanamycin before being spread plated onto an SBM plate containing 5\% (v/v) sucrose for counterselection. The resulting colonies were screened for double crossovers by kanamycin sensitivity and colony PCR before the final mutant was verified by PCR and Sanger sequencing.

\section{Identification of LuxR-type binding site}

Nucleotide sequences were identified as putative LuxR-type binding sites if they satisfied the following criteria: (1) located within 400 bp upstream of the translational start site, (2) matched the general NNCTG$\mathrm{N}_{10}$-CAGNN pattern with one mismatch or less, and (3) contained eight or more base pairs with dyad symmetry $(10,19)$.

\section{Acyl-HSL reporter assay}

The reporter assay was performed as described in (20). Briefly, cultures were centrifuged at $16,000 \mathrm{~g}$ and the supernatant from a wild-type (WT) culture of $2052 \mathrm{~S}$ was extracted twice with an equal volume of ethyl acetate containing $0.01 \%(\mathrm{v} / \mathrm{v})$ acetic acid. The organic phase was subsequently dried via nitrogen stream. The dried extract was then resuspended in acidified ethyl acetate, aliquoted into $1.5 \mathrm{~mL}$ tubes, and before being re-dried before an overnight $E$. coli reporter strain diluted to an OD of 0.1 was added to the tube. After four hours of incubation (37C, $200 \mathrm{rpm}$ ), GFP fluorescence (485-nm excitation, 510-nm emission) and absorbance at $600 \mathrm{~nm}$ were measured in a 96-well black, clear-bottomed plate by using a plate reader (SpectraMax i3x). 


\section{Isolation and characterization of the QS signal} The acyl-HSL signal produced by $2052 \mathrm{~S}$ was extracted from supernatant of a $50 \mathrm{~mL}$ culture extracted at early stationary phase $\left(\mathrm{OD}_{600 \mathrm{~mm}}=1.2,32\right.$ hours $)$ as described above. The supernatant extract was resuspended in methanol and $20 \%$ (from $10 \mathrm{~mL}$ of culture) was separated by HPLC using a Waters SunFire $\mathrm{C}_{18}$ column $(4.6 \times 100 \mathrm{~mm}, 5 \mu \mathrm{m})$ at $1.0 \mathrm{ml} / \mathrm{min}$ using a linear gradient of $10 \%$ to $100 \%$ methanol in water over 50 minutes. A $5-\mu \mathrm{l}$ aliquot of each $1.0-\mathrm{ml}$ fraction was analyzed using the $E$. coli reporter strain described above. The pooled adjacent fractions that showed GFP activity were then analyzed using highresolution tandem mass spectrometry. Confirmation of the identified signal was performed using a $\mathrm{C}_{10^{-}}$ HSL standard purchased from Cayman Chemical.

\section{RNA preparation}

Exponentially growing cultures of $2052 \mathrm{~S}$ were diluted to an $\mathrm{OD}_{600 \mathrm{~nm}}$ of 0.01 and were grown until logphase ( $\mathrm{OD}_{600 \mathrm{~nm}}$ of $0.8,24$ hours) prior to RNA extraction. For $\Delta t b a I+\mathrm{C}_{10}-\mathrm{HSL}$ signal, $2 \mathrm{mM} \mathrm{C}_{10}-\mathrm{HSL}$ in DMSO was added to a final concentration of $2 \mu \mathrm{M}$ every 12 hours. Subsequently, cultures were chilled on ice and then centrifuged at $4700 \mathrm{rpm}$ for $15 \mathrm{~min}$ at $4^{\circ} \mathrm{C}$. Pellets were then stored at $-80^{\circ} \mathrm{C}$ until further processing. Cell pellets were lysed by bead beating with $0.1-\mathrm{mm}$ zirconia-silica beads in $1 \mathrm{ml}$ TRIzol (ThermoFisher). $200 \mu \mathrm{L}$ of chloroform was then added and the mixture was separated by centrifugation using phasemaker tubes (ThermoFisher). Subsequently 1.5 volumes of $100 \%$ ethanol was added to the aqueous phase of the extract, which was then used for DNase I treatment (Invitrogen) and cleanup using an Invitrogen RNA PureLink mini kit according to the manufacturer's instructions. The resulting purified RNA was checked for DNA contamination by Nanodrop and PCR using the degenerate $16 \mathrm{~S}$ primers $27 \mathrm{~F}$ and $1492 \mathrm{R}$.

\section{RT-qPCR}

cDNA was prepared for RT-qPCR by reverse transcribing one microgram of the extracted RNA using iScript Reverse Transcription Supermix (BioRad). qPCR was performed using iTaq- Universal SYBR Green Supermix (BioRad) containing $400 \mathrm{nM}$ primers and cDNA normalized across all samples in a total volume of $10 \mu \mathrm{L}$. qPCR reactions were performed on a BioRad CFX Opus 96 thermal cycler, and threshold cycle $\left(\mathrm{C}_{\mathrm{T}}\right)$ values were calculated using BioRad CFX Maestro software. All primers and their corresponding gene targets are listed in Table 3.

\section{High-resolution LC-MS/MS for acyl-HSL identification}

Mass spectrometry data were collected using a Waters Acquity I-class ultra-high pressure liquid chromatograph coupled to a Waters Xevo G2-S quadrupole time-of-flight mass spectrometer. An Acquity UPLC BEH C 18 column $(2.1 \times 50 \mathrm{~mm})$ was used for separation of samples. Solvent A: Water $+0.1 \%(\mathrm{v} / \mathrm{v})$ formic acid, Solvent B: Acetonitrile $+0.1 \%(\mathrm{v} / \mathrm{v})$ formic acid. The sample was eluted from the column using a ten-minute linear solvent gradient: $0-0.1 \mathrm{~min}, 1 \% \mathrm{~B} ; 0.1-10 \mathrm{~min}, 100 \% \mathrm{~B}$. The solvent flow rate was $0.45 \mathrm{~mL}$ min-1. Mass spectra were collected in positive ion mode, with following parameters: $3 \mathrm{kV}$ capillary voltage; $25 \mathrm{~V}$ sampling cone voltage; $150{ }^{\circ} \mathrm{C}$ source temperature; $500^{\circ} \mathrm{C}$ desolvation temperature; nitrogen desolvation at $800 \mathrm{~L} / \mathrm{hr}$. The fragmentation spectra were collected using the same parameters with a $10-25 \mathrm{eV}$ collision energy ramp. The lockspray solution was $200 \mathrm{pg} / \mu \mathrm{L}$ leucine enkephalin. The lockspray flow rate was $6 \mu \mathrm{L} / \mathrm{min}$. Sodium formate was used to calibrate the mass spectrometer.

\section{Untargeted high-resolution LC-MS/MS for molecular networking}

HR-MS/MS data was obtained from 100\% methanol elution of HP-20 Diaion resin (Sigma) incubated with culture supernatant for at least 4 hours collected from a late log phase (48 hours) culture of WT, $\Delta t b a I$, $\Delta 2886, \Delta 2886+$ pAWP275 and $\Delta t b a I+\mathrm{C}_{10}$-HSL $(2 \mu \mathrm{M}$ supplemented every 12 hours). Samples were passed through an $\mathrm{C}_{18}$ solid phase extraction cartridge prior to dissolving in $50 \% \mathrm{ACN} / \mathrm{H} 2 \mathrm{O}$ at a final concentration of $1.0 \mathrm{mg} / \mathrm{mL}$. For data collection, the suggested settings for Waters mass spectrometer in (21) were used. An Acquity UPLC BEH C 18 column $(2.1 \times 50 \mathrm{~mm})$ was used for separation of samples. 310 Solvent A: Water $+0.1 \%(\mathrm{v} / \mathrm{v})$ formic acid, Solvent B: Acetonitrile $+0.1 \%(\mathrm{v} / \mathrm{v})$ formic acid. A flow rate 
of $0.6 \mathrm{~mL} / \mathrm{min}$ was used with the following gradient: $1 \%-100 \% \mathrm{~B}, 0-12 \mathrm{~min} ; 100 \% \mathrm{~B}, 12-13 \mathrm{~min}$; and a column reconditioning phase until $15 \mathrm{~min}$. The following parameters were used: $2.5 \mathrm{kV}$ capillary voltage; $20 \mathrm{~V}$ sampling cone voltage; $120{ }^{\circ} \mathrm{C}$ source temperature; $350{ }^{\circ} \mathrm{C}$ desolvation temperature; desolvation gas flow at $800 \mathrm{~L} / \mathrm{hr}$. MS ${ }^{1}$ acquisition range was set to $\mathrm{m} / \mathrm{z} 100-1,500$ with a scan time of $0.1 \mathrm{~s}$ in datadependent acquisition mode. The top 5 most abundant $\mathrm{MS}^{1}$ ions were selected in each scan and up to five $\mathrm{MS}^{2}$ scans in CID mode was acquired with $0.1 \mathrm{~s}$ scan time in positive mode. MS survey was set to switch to MS2 acquisition when TIC rises above an intensity of $5.0 \times 10^{3}$, and $\mathrm{MS}^{2}$ acquisition switch back to MS survey after $0.25 \mathrm{~s}$ have elapsed. The collision energy gradient was set to gradient parameters for as follows: 20 to $40 \mathrm{~V}$ for $100 \mathrm{Da}$ to 60 to $80 \mathrm{~V}$ for $1500 \mathrm{Da}$.

\section{Molecular Networking}

A molecular network was created using the online workflow (https://ccmsucsd.github.io/GNPSDocumentation/) on the GNPS website (http://gnps.ucsd.edu). The data was filtered by removing all MS/MS fragment ions within $\pm 17 \mathrm{Da}$ of the precursor $\mathrm{m} / \mathrm{z}$. MS/MS spectra were window filtered by choosing only the top 6 fragment ions in the $\pm 50 \mathrm{Da}$ window throughout the spectrum. The precursor ion mass tolerance was set to $0.02 \mathrm{Da}$ and a MS/MS fragment ion tolerance of $0.02 \mathrm{Da}$. A network was then created where edges were filtered to have a cosine score above 0.7 and more than 6 matched peaks. Further, edges between two nodes were kept in the network if and only if each of the nodes appeared in each other's respective top 10 most similar nodes. Finally, the maximum size of a molecular family was set to 100, and the lowest scoring edges were removed from molecular families until the molecular family size was below this threshold. The spectra in the network were then searched against GNPS spectral libraries $(22,23)$. The library spectra were filtered in the same manner as the input data. All matches kept between network spectra and library spectra were required to have a score above 0.7 and at least 6 matched peaks. The DEREPLICATOR was used to annotate MS/MS spectra (24). The molecular networks were visualized using Cytoscape software (25).

\section{Data Deposition and Job Accessibility}

The mass spectrometry data were deposited in the public repository MassIVE: https://massive.ucsd.edu/ProteoSAFe/dataset.jsp?task=f823719f2c5f4fca903bfe49f6964f45. The molecular networking job can be publicly accessed at: https://gnps.ucsd.edu/ProteoSAFe/status.jsp?task=d4ce2cc7d4db423eb00a4d2876993b50.

\section{AUTHOR CONTIBUTIONS}

JMDR and AWP designed experiments. JMDR and EGM performed experiments. MAA isolated 2052S. GPC, MGH, and AWP oversaw and supported the research. JMDR and AWP wrote the manuscript. All authors have read and approved of the final version of the manuscript.

\section{CONFLICTS OF INTEREST}

The authors declare no conflicts of interest.

\section{COMPLIANCE}

The work was completed under supervision of the Department of Agriculture-Bureau of Fisheries and Aquatic Resources, Philippines (DA-BFAR), in compliance with all required legal instruments and regulatory issuances covering the conduct of the research. 


\section{ACKNOWLEDGEMENTS}

We thank D. Petras (University of Tübingen) for reading the manuscript and providing helpful advice on the molecular networking analysis. We thank H. Naka (University of Utah) for initial help with $T$.

turnerae genetics. This work was supported by National Institutes of Health grant R00 GM118762 (to AWP) and National Institutes of Health Fogarty International Center Philippine Mollusk SymbiontInternational Cooperative Biodiversity Group (PMS-ICBG) grant U19TW008163 (to GPC and MGH). This work was also supported by funding from the Undergraduate Research Opportunities Program at the University of Utah (to EGM). 
Table 1. Strains and plasmids used in this study.

\begin{tabular}{|c|c|c|c|}
\hline Strain or plasmid & $\begin{array}{l}\text { Puri Lab } \\
\text { Strain/Plasmid } \\
\text { Collection } \\
\text { Number }\end{array}$ & Description & $\begin{array}{l}\text { Source or } \\
\text { reference }\end{array}$ \\
\hline \multicolumn{4}{|c|}{ Strains } \\
\hline E. coli TOP10 & EAWP2 & $\begin{array}{l}\mathrm{F}-\text { mcrA } \Delta(\text { mrr-hsdRMS-mcrBC }) \\
\text { Ф80lacZ } \Delta \mathrm{M} 15 \Delta \text { lacX74 recAl araD139 } \\
\Delta(\text { ara leu }) 7697 \text { galU galK rpsL }\left(\mathrm{Str}^{\mathrm{R}}\right) \\
\text { endA1 nupG }\end{array}$ & Invitrogen \\
\hline E. coli S17-1 $\lambda$ pir & EAWP3 & $\begin{array}{l}\text { Donor strain. } \mathrm{Tp}^{\mathrm{R}} \mathrm{Sm}^{\mathrm{R}} \text { recA thi pro hsd( } \mathrm{r}^{-} \\
\left.\mathrm{m}^{+}\right) \mathrm{RP} 4-2-\mathrm{Tc}:: \mathrm{Mu}: \mathrm{Km} \operatorname{Tn} 7 \text { pir }\end{array}$ & $(18)$ \\
\hline $\begin{array}{l}\text { Teredinibacter } \text { sp. } \\
\text { 2052S.S.stab0a.01 }\end{array}$ & AWP283 & $\begin{array}{l}\text { Shipworm symbiont isolated from the gills } \\
\text { of Bactronophorus cf. thoracites. }\end{array}$ & $\begin{array}{l}\text { (3) } \\
\text { (Table S1) }\end{array}$ \\
\hline $\begin{array}{l}\text { Teredinibacter } \mathrm{sp} . \\
\text { 2052S.S.stab0a.01 } \\
\Delta t \text { tbaI }\end{array}$ & AWP284 & $\begin{array}{l}\text { Shipworm symbiont isolated from the gills } \\
\text { of Bactronophorus cf. thoracites. } \Delta \text { tbaI }\end{array}$ & This study \\
\hline $\begin{array}{l}\text { Teredinibacter } \mathrm{sp.} \\
\text { 2052S.S.stab0a.01 } \\
\Delta 2886\end{array}$ & AWP285 & $\begin{array}{l}\text { Shipworm symbiont isolated from the gills } \\
\text { of Bactronophorus cf. thoracites. } \Delta 2886\end{array}$ & This study \\
\hline $\begin{array}{l}\text { Teredinibacter } \mathrm{sp} . \\
\text { 2052S.S.stab0a.01 } \\
\Delta 2886+\text { pAWP275 }\end{array}$ & AWP286 & $\begin{array}{l}\text { Shipworm symbiont isolated from the gills } \\
\text { of Bactronophorus cf. thoracites. } \Delta 2886+ \\
\text { pAWP275, Kan }{ }^{\mathrm{R}}\end{array}$ & This study \\
\hline $\begin{array}{l}\text { E. coli reporter } \\
\text { strain } \mathrm{P}_{t b a t} g f p\end{array}$ & EAWP128 & $\begin{array}{l}\text { Acyl-HSL reporter strain; } E \text {. coli } \mathrm{TOP} 10 \\
\text { with pAWP239 and pAWP240, } \operatorname{Kan}^{\mathrm{R}} \mathrm{Cm}^{\mathrm{R}}\end{array}$ & This study \\
\hline $\begin{array}{l}\text { E. coli reporter } \\
\text { strain } \mathrm{P}_{2886}-g f p\end{array}$ & EAWP201 & $\begin{array}{l}\text { Acyl-HSL reporter strain; } E \text {. coli TOP10 } \\
\text { with pAWP381 and pAWP240, } \operatorname{Kan}^{\mathrm{R}} \mathrm{Cm}^{\mathrm{R}}\end{array}$ & This study \\
\hline $\begin{array}{l}\text { E. coli reporter } \mathrm{P}_{t b a l-} \\
\text { lmut } g f p\end{array}$ & EAWP202 & $\begin{array}{l}\text { Acyl-HSL reporter strain; E. coli TOP10 } \\
\text { with pAWP479 and pAWP240, } \operatorname{Kan}^{\mathrm{R}} \mathrm{Cm}^{\mathrm{R}}\end{array}$ & This study \\
\hline $\begin{array}{l}\text { E. coli reporter } \\
\text { strain } \mathrm{P}_{t b a l-2 \mathrm{mut}} \mathrm{gfp}\end{array}$ & EAWP203 & $\begin{array}{l}\text { Acyl-HSL reporter strain; E. coli TOP10 } \\
\text { with pAWP480 and pAWP240, } \operatorname{Kan}^{\mathrm{R}} \mathrm{Cm}^{\mathrm{R}}\end{array}$ & This study \\
\hline \multicolumn{4}{|c|}{ Plasmids } \\
\hline pPROBE- $g f p[\mathrm{LVA}]$ & \multicolumn{2}{|c|}{ Promoter probe vector } & $(17)$ \\
\hline pACYC184 & \multicolumn{2}{|c|}{ Replicating vector containing the $\mathrm{p} 15 \mathrm{~A}$ origin of replication } & $(26)$ \\
\hline pCM433kanT & \multicolumn{2}{|c|}{$\begin{array}{l}\text { Sucrose counterselection vector for constructing in-frame, } \\
\text { unmarked deletion mutants }\end{array}$} & $(27)$ \\
\hline pBBR1MCS-2 & \multicolumn{2}{|c|}{ Broad host range replicating vector } & $(28)$ \\
\hline pAWP239 & \multicolumn{2}{|c|}{$\begin{array}{l}\text { pPROBE- } g f p \text { [LVA] containing tbaI promoter ( } 421 \text { bp upstream } \\
\text { of K256DRAFT 2891) fused to } g f p\end{array}$} & This study \\
\hline pAWP240 & \multicolumn{2}{|c|}{$\begin{array}{l}\text { pACYC184 expressing tbaR K256DRAFT_2894) under its } \\
\text { native promotor ( } 400 \mathrm{bp} \text { upstream sequence) }\end{array}$} & This study \\
\hline pAWP381 & \multicolumn{2}{|c|}{$\begin{array}{l}\text { pPROBE- } g f p[\text { LVA] containing K256DRAFT_2886 promoter } \\
\text { ( } 421 \text { bp upstream sequence) fused to } g f p\end{array}$} & This study \\
\hline pAWP378 & \multicolumn{2}{|c|}{$\begin{array}{l}\text { pCM433kanT containing flanks to create in-frame, unmarked } \\
\text { deletion of tbaI (K256DRAFT_2891) }\end{array}$} & This study \\
\hline pAWP387 & \multicolumn{2}{|c|}{$\begin{array}{l}\text { pCM433kanT containing flanks to create in-frame, unmarked } \\
\text { deletion of K256DRAFT } 2886\end{array}$} & This study \\
\hline
\end{tabular}




\begin{tabular}{|c|c|c|}
\hline pAWP275 & $\begin{array}{l}\text { pBBR1MCS-2 containing K256DRAFT_2886 driven by the } \\
\text { 2052S rpoD promoter (300 bp upstream sequence of } \\
\text { K256DRAFT 2811) }\end{array}$ & This study \\
\hline pAWP479 & $\begin{array}{l}\text { pPROBE- } g f p[\mathrm{LVA}] \text { containing } \mathrm{P}_{t b a l-1 \mathrm{mut}} \text { promoter fused to } g f p \text {, } \\
\text { pAWP239 with mutation of CT to TA in } t b a I \text { promoter in } \\
\text { putative TbaR binding site } \mathrm{P}_{t b a I-1} \\
\text { (AGCTGTCTAATCCGACAGCG to } \\
\text { AGTAGTCTAATCCGACAGC) (Figure 1B) }\end{array}$ & This study \\
\hline pAWP480 & $\begin{array}{l}\text { pPROBE- } g f p[\mathrm{LVA}] \text { containing } \mathrm{P}_{t b a I-2 m u t} \text { promoter fused to } g f p \\
\text { pAWP239 with mutation of CT to TA in } t b a I \text { promoter in } \\
\text { putative TbaR binding site } \mathrm{P}_{t b a I-2} \\
\text { (ACCTGTACAATCTTGCAGTA to } \\
\text { ACTAGTACAATCTTGCAGTA) (Figure 1B) }\end{array}$ & This study \\
\hline
\end{tabular}


Table 2. Cloning and diagnostic primers used in this study.

\begin{tabular}{|c|c|c|}
\hline Primer & Sequence (5' to 3') & Description \\
\hline $\begin{array}{l}\text { oAWP186_433KTV1_fw } \\
\text { d }\end{array}$ & ATGTGCAGGTTGTCGGTGTC & \multirow{4}{*}{$\begin{array}{l}\text { For } \\
\text { amplifying the } \\
\text { pCM433kanT } \\
\text { backbone in } \\
\text { two pieces }\end{array}$} \\
\hline $\begin{array}{l}\text { oAWP160_433KTV1_re } \\
\text { V }\end{array}$ & $\begin{array}{l}\text { ATAAAGGTGAATCCCATAGGGCAGGA } \\
\text { GCTATAATCTCGAGTCCCGTCAAG }\end{array}$ & \\
\hline $\begin{array}{l}\text { oAWP159_433KTV2_fw } \\
\text { d }\end{array}$ & TAGCTCCTGCCCTATGGGAT & \\
\hline $\begin{array}{l}\text { oAWP187_433KTV2_re } \\
\text { v }\end{array}$ & TGGTAACTGTCAGACCAAGTTTACTC & \\
\hline $\begin{array}{l}\text { oAWP937_239I_SacI_fw } \\
\text { d }\end{array}$ & GGTGGTGAGCTCAATGATTGTGCCGAAATTATTG & \multirow{2}{*}{$\begin{array}{l}\text { For } \\
\text { amplifying } \\
\text { tbaI upstream } \\
\text { region to } \\
\text { insert into } \\
\text { pPROBE- } \\
g f p[\mathrm{LVA}] \\
\text { promoter } \\
\text { probe vector. } \\
\text { Also used on } \\
\text { gBlocks of } \\
\mathrm{P}_{\text {tbaI-1mut }} \text { and } \\
\mathrm{P}_{\text {tbal-2mut }}\end{array}$} \\
\hline $\begin{array}{l}\text { oAWP938_239I_EcoRI_r } \\
\text { ev }\end{array}$ & GGTGGTGAATTCAGTAATTACGATTGTGTTCA & \\
\hline oAWP939_240I_fwd & $\begin{array}{l}\text { CCTAATGCAGGAGTCGCATAATGGGGGTAATAT } \\
\text { TTAACACGC }\end{array}$ & \multirow{2}{*}{$\begin{array}{l}\text { For } \\
\text { amplifying } \\
\text { tbaR and } \\
400 \mathrm{bp} \\
\text { upstream to } \\
\text { insert into } \\
\text { pACYC184 }\end{array}$} \\
\hline oAWP940_240I_rev & $\begin{array}{l}\text { CGTTGACTCTCAGTCATAGTTCAGGGCGTCGGCT } \\
\text { TAATTAA }\end{array}$ & \\
\hline oAWP1558 & $\begin{array}{l}\text { ATATGAGTAAACTTGGTCTGACAGTTACCAGAC } \\
\text { AGGCTGTTGATCTTTCCA }\end{array}$ & \multirow{4}{*}{$\begin{array}{l}\text { For } \\
\text { amplifying } \\
\text { flanks to } \\
\text { create } \Delta t b a I \\
\text { in-frame, } \\
\text { unmarked } \\
\text { deletion }\end{array}$} \\
\hline oAWP1559 & $\begin{array}{l}\text { GGTGTGGATTGCGAGCATATCCTTTTCGCCCCCG } \\
\text { TT }\end{array}$ & \\
\hline oAWP1560 & $\begin{array}{l}\text { GGCGAAAAGGATATGCTCGCAATCCACACCCAC } \\
\text { TGA }\end{array}$ & \\
\hline oAWP1561 & $\begin{array}{l}\text { CGTGCATCACGACACCGACAACCTGCACATCGA } \\
\text { GCGGCTTCAGCAGCAAAA }\end{array}$ & \\
\hline oAWP1426_010U_fwd & $\begin{array}{l}\text { TCCTGTTGAAAGTAACATAGTGAGAGTCCTTCTT } \\
\text { GCT }\end{array}$ & \multirow{4}{*}{$\begin{array}{l}\text { For } \\
\text { amplifying } \\
\text { flanks to } \\
\text { create } \Delta 2886 \\
\text { in-frame, } \\
\text { unmarked } \\
\text { deletion }\end{array}$} \\
\hline oAWP1432_010U_rev & $\begin{array}{l}\text { ATATGAGTAAACTTGGTCTGACAGTTACCACCG } \\
\text { AGGAAAATACTGCCCATT }\end{array}$ & \\
\hline oAWP1428_010D_fwd & $\begin{array}{l}\text { AGGACTCTCACTATGTTACTTTCAACAGGACAAT } \\
\text { GACC }\end{array}$ & \\
\hline oAWP1429_010D_rev & $\begin{array}{l}\text { CGTGCATCACGACACCGACAACCTGCACATTCG } \\
\text { AGCATGTAGACCTCATGG }\end{array}$ & \\
\hline oAWP1418_009I_rev & $\begin{array}{l}\text { GCGGGGATCTCATGCTGGAGTTCTTCGCCCTCAT } \\
\text { TGTCCTGTTGAAAGTAAA }\end{array}$ & \multirow{2}{*}{$\begin{array}{l}\text { For } \\
\text { amplifying } \\
\text { K256DRAFT } \\
2886 \text { to fuse }\end{array}$} \\
\hline oAWP1419_009I_fwd & $\begin{array}{l}\text { TCCGCAGGACTTTTAATGTCTCAAGTATTTATGT } \\
\text { TTCC }\end{array}$ & \\
\hline
\end{tabular}




\begin{tabular}{|c|c|c|}
\hline & & $\begin{array}{l}\text { downstream } \\
\text { of } 2052 \mathrm{~S} \\
\text { rpoD } \\
\text { promoter and } \\
\text { insert into } \\
\text { pBBR1MCS-2 }\end{array}$ \\
\hline $\begin{array}{l}\text { oAWP1420_PrpoD_009I } \\
\text { fwd }\end{array}$ & $\begin{array}{l}\text { CAGTCACGACGTTGTAAAACGACGGCCAGTAGG } \\
\text { AAGCCAGCAAGCGGGAA }\end{array}$ & \multirow{2}{*}{$\begin{array}{l}\text { For } \\
\text { amplifying } \\
2052 \mathrm{~S} \text { rpoD } \\
\text { promoter to } \\
\text { fuse with the } \\
\text { K256DRAFT } \\
\text { 2886 gene } \\
\end{array}$} \\
\hline $\begin{array}{l}\text { oAWP1421_PrpoD_009I } \\
\text { rev }\end{array}$ & $\begin{array}{l}\text { AAATACTTGAGACATTAAAAGTCCTGCGGAGAT } \\
\text { TGGAG }\end{array}$ & \\
\hline $\begin{array}{l}\text { oAWP1402_004I_SacI_f } \\
\text { wd }\end{array}$ & $\begin{array}{l}\text { GGTGGTGAGCTCGAACTTCTTCAGGGTGAAGAA } \\
\text { GCTC }\end{array}$ & \multirow[b]{2}{*}{$\begin{array}{l}\text { For } \\
\text { amplifying } \\
\text { K256DRAFT } \\
2886 \\
\text { upstream } \\
\text { region to } \\
\text { insert into } \\
\text { pPROBE- } \\
g f p[\text { LVA }] \\
\text { promoter } \\
\text { probe vector }\end{array}$} \\
\hline $\begin{array}{l}\text { oAWP1403_004I_EcoRI } \\
\text { rev }\end{array}$ & $\begin{array}{l}\text { GGTGGTGAATTCGCCAATAATTGCAATATCCATG } \\
\text { TG }\end{array}$ & \\
\hline oAWP1488_rev & GCGCCGTCACTATCGATCTTGT & \multirow[b]{2}{*}{$\begin{array}{l}\text { For } \\
\text { determining if } \\
\text { tbaI and } \\
\text { K256DRAFT } \\
2890 \text { are } \\
\text { transcribed in } \\
\text { the same } \\
\text { operon }\end{array}$} \\
\hline oAWP1489_fwd & TTCGCCAGTCCCAACGACTTGC & \\
\hline
\end{tabular}

Table 3. Reverse transcription quantitative PCR primers used in this study.

\begin{tabular}{|l|l|l|}
\hline Primer & Sequence (5' to 3') & Target \\
\hline oAWP1064_qPCR_16s_fwd & AAGCAACGCGAAGAACCTTA & 16s rRNA reference gene \\
\cline { 1 - 2 } oAW1065_qPCR_16s_rev & CACCGGCAGTCTCCTTAGAG & \\
\hline oAWP1564_qPCR_ctg2827 fwd & AAATACCTGCTCGCGTCCGCT & 2052S trans-AT PKS gene, \\
\hline oAWP1565_qPCR_ctg2827_rev & TCGCTTTATGGACGCCTGCG & K256DRAFT_2890 \\
\hline oAWP1068_qPCR_ctg2823_fwd & GTAGCACTCGGGGTGATTGT & 2052S PKS gene, \\
\cline { 1 - 2 } oAWP1069_qPCR_ctg2823_rev & ACAGCCTTGGGGAATATGTG & K256DRAFT_2886 \\
\hline oAWP1566_qPCR_ctg2819_fwd & GTCACCTGCAATTCCGGTGTG & 2052S NRPS gene, \\
\cline { 1 - 2 } oAWP1567_qPCR_ctg2819_rev & ATGCCGGCGCAATTTGTGGTG & K256DRAFT_2882 \\
\hline
\end{tabular}




\section{REFERENCES}

1. Distel DL, Beaudoin DJ, Morrill W. 2002. Coexistence of Multiple Proteobacterial Endosymbionts in the Gills of the Wood-Boring Bivalve Lyrodus pedicellatus (Bivalvia: Teredinidae). Appl Environ Microbiol https://doi.org/10.1128/AEM.68.12.6292-6299.2002.

2. Waterbury JB, Calloway CB, Turner RD. 1983. A Cellulolytic Nitrogen-Fixing Bacterium Cultured from the Gland of Deshayes in Shipworms (Bivalvia: Teredinidae). Science https://doi.org/10.1126/science.221.4618.1401

3. Altamia MA, Lin Z, Trindade-Silva AE, Uy ID, Shipway JR, Wilke DV, Concepcion GP, Distel DL, Schmidt EW, Haygood MG. 2020. Secondary Metabolism in the Gill Microbiota of Shipworms (Teredinidae) as Revealed by Comparison of Metagenomes and Nearly Complete Symbiont Genomes. mSystems https://doi.org/10.1128/mSystems.00261-20

4. O’Connor RM, V FJN, Abenoja J, Bowden G, Reis P, Beaushaw J, Relat RMB, Driskell I, Gimenez F, Riggs MW, Schaefer DA, Schmidt EW, Lin Z, Distel DL, Clardy J, Ramadhar TR, Allred DR, Fritz HM, Rathod P, Chery L, White J. 2020. A symbiotic bacterium of shipworms produces a compound with broad spectrum anti-apicomplexan activity. PLoS Pathog https://doi.org/10.1371/journal.ppat.1008600

5. Rutherford ST, Bassler BL. 2012. Bacterial quorum sensing: its role in virulence and possibilities for its control. Cold Spring Harb Perspect Med https://doi.org/10.1101/cshperspect.a012427

6. Schuster M, Joseph Sexton D, Diggle SP, Peter Greenberg E. 2013. Acyl-Homoserine Lactone Quorum Sensing: From Evolution to Application. Annu Rev Microbiol https://doi.org/10.1146/annurev-micro-092412-155635

7. Eberhard A, Burlingame AL, Eberhard C, Kenyon GL, Nealson KH, Oppenheimer NJ. 1981. Structural identification of autoinducer of Photobacterium fischeri luciferase. Biochemistry https://doi.org/10.1021/bi00512a013

8. Visick KL, Foster J, Doino J, McFall-Ngai M, Ruby EG. 2000. Vibrio fischeri lux Genes Play an Important Role in Colonization and Development of the Host Light Organ. J Bacteriol https://doi.org/10.1128/JB.182.16.4578-4586.2000

9. McGowan S, Sebaihia M, Jones S, Yu B, Bainton N, Chan PF, Bycroft B, Stewart GSAB, Williams P, Salmond GPCY 1995. Carbapenem antibiotic production in Erwinia carotovora is regulated by CarR, a homologue of the LuxR transcriptional activator. Microbiology https://doi.org/10.1099/13500872-141-3-541

10. Puri AW, Schaefer AL, Fu Y, Beck DAC, Greenberg EP, Lidstrom ME. 2016. Quorum Sensing in a Methane-Oxidizing Bacterium. J Bacteriol https://doi.org/10.1128/JB.00773-16

11. Seyedsayamdost MR, Chandler JR, Blodgett JAV, Lima PS, Duerkop BA, Oinuma K-I, Greenberg EP, Clardy J. 2010. Quorum-sensing-regulated bactobolin production by Burkholderia thailandensis E264. Org Lett https://doi.org/10.1021/o1902751x

12. Brotherton CA, Medema MH, Greenberg EP. 2018. luxR Homolog-Linked Biosynthetic Gene Clusters in Proteobacteria. mSystems https://doi.org/10.1128/mSystems.00208-17 
13. Nothias L-F, Petras D, Schmid R, Dührkop K, Rainer J, Sarvepalli A, Protsyuk I, Ernst M, Tsugawa H, Fleischauer M, Aicheler F, Aksenov AA, Alka O, Allard P-M, Barsch A, Cachet X, CaraballoRodriguez AM, Da Silva RR, Dang T, Garg N, Gauglitz JM, Gurevich A, Isaac G, Jarmusch AK, Kameník Z, Kang KB, Kessler N, Koester I, Korf A, Le Gouellec A, Ludwig M, Martin H. C, McCall L-I, McSayles J, Meyer SW, Mohimani H, Morsy M, Moyne O, Neumann S, Neuweger H, Nguyen NH, Nothias-Esposito M, Paolini J, Phelan VV, Pluskal T, Quinn RA, Rogers S, Shrestha B, Tripathi A, van der Hooft JJJ, Vargas F, Weldon KC, Witting M, Yang H, Zhang Z, Zubeil F, Kohlbacher O, Böcker S, Alexandrov T, Bandeira N, Wang M, Dorrestein PC. 2020. Feature-based molecular networking in the GNPS analysis environment. Nat Methods https://doi.org/10.1038/s41592-020-0933-6

14. Chen I-MA, Chu K, Palaniappan K, Ratner A, Huang J, Huntemann M, Hajek P, Ritter S, Varghese N, Seshadri R, Roux S, Woyke T, Eloe-Fadrosh EA, Ivanova NN, Kyrpides NC. 2021. The IMG/M data management and analysis system v.6.0: new tools and advanced capabilities. Nucleic Acids Res https://doi.org/10.1093/nar/gkaa939

15. Blin K, Shaw S, Kloosterman AM, Charlop-Powers Z, van Wezel GP, Medema MH, Weber T. 2021. antiSMASH 6.0: improving cluster detection and comparison capabilities. Nucleic Acids Res https://doi.org/10.1093/nar/gkab335

16. Gibson DG, Young L, Chuang R-Y, Venter JC, Hutchison CA, Smith HO. 2009. Enzymatic assembly of DNA molecules up to several hundred kilobases. Nat Methods https://doi.org/10.1038/nmeth.1318

17. Miller WG, Leveau JH, Lindow SE. 2000. Improved $g f p$ and inaZ broad-host-range promoter-probe vectors. Mol Plant Microbe Interact https://doi.org/10.1094/MPMI.2000.13.11.1243

18. Simon R, Priefer U, Pühler A. 1983. A Broad Host Range Mobilization System for in vivo Genetic Engineering: Transposon Mutagenesis in Gram Negative Bacteria. Nat Biotechnol https://doi.org/10.1038/nbt1183-784

19. Antunes LCM, Ferreira RBR, Lostroh CP, Greenberg EP. 2008. A mutational analysis defines Vibrio fischeri LuxR binding sites. J Bacteriol https://doi.org/10.1128/JB.01443-07

20. Antunes LCM, Schaefer AL, Ferreira RBR, Qin N, Stevens AM, Ruby EG, Greenberg EP. 2007. Transcriptome analysis of the Vibrio fischeri LuxR-LuxI regulon. J Bacteriol https://doi.org/10.1128/JB.00736-07

21. Aron AT, Gentry EC, McPhail KL, Nothias L-F, Nothias-Esposito M, Bouslimani A, Petras D, Gauglitz JM, Sikora N, Vargas F, van der Hooft JJJ, Ernst M, Kang KB, Aceves CM, CaraballoRodríguez AM, Koester I, Weldon KC, Bertrand S, Roullier C, Sun K, Tehan RM, Boya P. CA, Christian MH, Gutiérrez M, Ulloa AM, Tejeda Mora JA, Mojica-Flores R, Lakey-Beitia J, VásquezChaves V, Zhang Y, Calderón AI, Tayler N, Keyzers RA, Tugizimana F, Ndlovu N, Aksenov AA, Jarmusch AK, Schmid R, Truman AW, Bandeira N, Wang M, Dorrestein PC. 2020. Reproducible molecular networking of untargeted mass spectrometry data using GNPS. Nat Protoc https://doi.org/10.1038/s41596-020-0317-5 Luzzatto-Knaan T, Porto C, Bouslimani A, Melnik AV, Meehan MJ, Liu W-T, Crüsemann M, Boudreau PD, Esquenazi E, Sandoval-Calderón M, Kersten RD, Pace LA, Quinn RA, Duncan KR, Hsu C-C, Floros DJ, Gavilan RG, Kleigrewe K, Northen T, Dutton RJ, Parrot D, Carlson EE, Aigle 
B, Michelsen CF, Jelsbak L, Sohlenkamp C, Pevzner P, Edlund A, McLean J, Piel J, Murphy BT, Gerwick L, Liaw C-C, Yang Y-L, Humpf H-U, Maansson M, Keyzers RA, Sims AC, Johnson AR, Sidebottom AM, Sedio BE, Klitgaard A, Larson CB, Boya P CA, Torres-Mendoza D, Gonzalez DJ, Silva DB, Marques LM, Demarque DP, Pociute E, O’Neill EC, Briand E, Helfrich EJN, Granatosky EA, Glukhov E, Ryffel F, Houson H, Mohimani H, Kharbush JJ, Zeng Y, Vorholt JA, Kurita KL, Charusanti P, McPhail KL, Nielsen KF, Vuong L, Elfeki M, Traxler MF, Engene N, Koyama N, Vining OB, Baric R, Silva RR, Mascuch SJ, Tomasi S, Jenkins S, Macherla V, Hoffman T, Agarwal V, Williams PG, Dai J, Neupane R, Gurr J, Rodríguez AMC, Lamsa A, Zhang C, Dorrestein K, Duggan BM, Almaliti J, Allard P-M, Phapale P, Nothias L-F, Alexandrov T, Litaudon M, Wolfender J-L, Kyle JE, Metz TO, Peryea T, Nguyen D-T, VanLeer D, Shinn P, Jadhav A, Müller R, Waters KM, Shi W, Liu X, Zhang L, Knight R, Jensen PR, Palsson BØ, Pogliano K, Linington RG, Gutiérrez M, Lopes NP, Gerwick WH, Moore BS, Dorrestein PC, Bandeira N. 2016. Sharing and community curation of mass spectrometry data with Global Natural Products Social Molecular Networking. Nat Biotechnol https://doi.org/10.1038/nbt.3597

23. Horai H, Arita M, Kanaya S, Nihei Y, Ikeda T, Suwa K, Ojima Y, Tanaka K, Tanaka S, Aoshima K, Oda Y, Kakazu Y, Kusano M, Tohge T, Matsuda F, Sawada Y, Hirai MY, Nakanishi H, Ikeda K, Akimoto N, Maoka T, Takahashi H, Ara T, Sakurai N, Suzuki H, Shibata D, Neumann S, Iida T, Tanaka K, Funatsu K, Matsuura F, Soga T, Taguchi R, Saito K, Nishioka T. 2010. MassBank: a public repository for sharing mass spectral data for life sciences. J Mass Spectrom https://doi.org/10.1002/jms.1777

24. Mohimani H, Gurevich A, Shlemov A, Mikheenko A, Korobeynikov A, Cao L, Shcherbin E, Nothias L-F, Dorrestein PC, Pevzner PA. 2018. Dereplication of microbial metabolites through database search of mass spectra. Nat Commun https://doi.org/10.1038/s41467-018-06082-8

25. Shannon P, Markiel A, Ozier O, Baliga NS, Wang JT, Ramage D, Amin N, Schwikowski B, Ideker T. 2003. Cytoscape: A Software Environment for Integrated Models of Biomolecular Interaction Networks. Genome Res https://doi.org/10.1101/gr.1239303

26. Chang AC, Cohen SN. 1978. Construction and characterization of amplifiable multicopy DNA cloning vehicles derived from the P15A cryptic miniplasmid. J Bacteriol https://doi.org/10.1128/jb.134.3.1141-1156.1978

27. Puri AW, Owen S, Chu F, Chavkin T, Beck DAC, Kalyuzhnaya MG, Lidstrom ME. 2014. Genetic Tools for the Industrially Promising Methanotroph Methylomicrobium buryatense. Appl Environ Microbiol https://doi.org/10.1128/AEM.03795-14

28. Kovach ME, Elzer PH, Steven Hill D, Robertson GT, Farris MA, Roop RM, Peterson KM. 1995. Four new derivatives of the broad-host-range cloning vector pBBR1MCS, carrying different antibiotic-resistance cassettes. Gene https://doi.org/10.1016/0378-1119(95)00584-1 